\title{
SEASONAL CHANGES OF SOME MICROBIOLOGICAL PROPERTIES OF SOILS IN A FIELD OF HAZELNUT (CORYLUS AVELLANA L.) GROWING
}

\author{
IRMAK YILMAZ, F. \\ Department of Soil Science and Plant Nutrition, Faculty of Agriculture, Ordu University, Ordu, \\ Turkey \\ (e-mail: fundairmak@hotmail.com; phone: +90-452-234-5010; fax: +90-452-226-5269) \\ (Received 30 ${ }^{\text {th }}$ Jul 2019; accepted $25^{\text {th }}$ Nov 2019)
}

\begin{abstract}
The aim of this study is to identify the effects of the compost obtained from hazelnut husks by using biological techniques, on soil quality at different sampling times. The composted hazelnut husk was used at 6 application doses and with 3 replications in order to increase the organic material content of the soils at doses of $0,0.5 \%, 1 \%, 2 \%, 3 \%$ and $4 \%$. The hazelnut husk compost was applied at the Akçatepe/Ordu/Turkey experiment area on the 23rd of November 2012 by using the mattock planting method. The soil samples were collected from the field at 4 different sampling seasons and consequently, various chemical and biological soil characteristics were detected. The results shows; certain doses and different sampling seasons have a significant effect on the beta-glucosidase, urease and acid phosphatase enzyme activities in soils; the most effective doses were $4 \%$ and $3 \%$; the 1st and 4th seasons provided the best results. As for other biological characteristics the highest values were as follows: $\mathrm{CO}_{2}$ production at $1 \%$ dose, microbial biomass-C value at $2 \%$ dose. The application of hazelnut husk compost, which has a rich organic matter content and is an organic material itself, to soils, promotes an increase in soil organic materials.
\end{abstract}

Keywords: hazelnut husk, compost, soil enzymes, organic material, microbial biomass-C

\section{Introduction}

The use of wastes, which have an important place in agricultural production, as an organic matter source for soils, has recently become a common practice. The utilization of wastes is also a solution for environmental pollution. Especially following the hazelnut (Corylus avellana L.) harvest season, its husk is either used as fuel, as cushions for animals or left aside as idle wastes. Especially in Turkey's Black Sea region, hazelnut is an important product. It is known that approximately 550.000 tons of shelled hazelnut is produced annually in this region. After the harvest, from $1 \mathrm{~kg}$ of fresh hazelnut, remains around 1/3 and from shelled hazelnut 1/5 (200 gr) of dry husk shell (Çalışkan et al., 1996; Bender Özenç, 2008; Amiri et al., 2017).

Turkey is the world's leading hazelnut producer, accounting for about $75 \%$ of world hazelnut supply. According to FAO data, Turkey is the first world hazelnut producer and exporter that covers approximately $70 \%$ and $82 \%$ of the world's production and export respectively. It is followed by Italy with nearly $20 \%$ in production and $15 \%$ in export. That is why the Turkey is at the focus of the international academic studies about hazelnut, hazelnut husk compost etc. and references about these issues (FAO, 2019). Solely $10 \%$ of the hazelnut consumption is accounted in-shell, the rest of this ratio is shelled and evaluated for industrial objectives (Tous, 2001; Stévigny et al., 2007).

Especially in Giresun, Ordu, Trabzon and Samsun in the Black Sea Region and Sakarya in the Marmara Region, hazelnut cultivation is the main source of living. The Black Sea Region's ecological structure is suitable for hazelnut production. Thus 
hazelnut is an essential product in Turkey's economy. Most densely in the Black Sea Region, hazelnut is produced in 39 provinces of Turkey. Hazelnut production is mainly run as family-owned businesses. According to Republic of Turkey Ministry of Agriculture and Forestry, around 395 thousand families are economically focused on hazelnut production with a total area of 700 thousand hectares (GTB, 2013). The increase in world's population, accelerates the agricultural activities on soils. The excessive and unconscious use of fertilizers and chemicals common in traditional agricultural system, generates both environmental and soil issues. Most of soil issues arise from the wrong or misuse of it, which ends up with the soil impairment. The soil is a natural and living substance, which together with air and water contains millions of microorganisms and provides an environment for human beings, plants and animals to live. Even the smallest piece of land needs thousands of years to form; hence, our soils are invaluable within the ecosystem. Especially the benefits provided by the environment that soils render for plant production, show how crucial it is for human being's life. A healthy soil means a healthy plant production environment, which eventually connotes that plants grown on such lands will be healthier. In order to ensure healthier plants, to protect their quality features, fertility and sustainability, it is necessary to protect the soil idiosyncrasy. All these features are related to the quality of soils, the sustainability or developability of some characteristics, which appear in the soil quality (Aygün, 2015).

Microbial biomass carbon, $\mathrm{CO}_{2}$ production (soil respiration) and dehydrogenase activity are commonly used parameters to identify the biological effects of organic and inorganic matters penetrated into the soils (Meli et al., 2002).

The application of hazelnut husk compost into the soils, provides an increase by means of organic matter, ensuring as a consequence many of its physical, chemical and biological features to improve. This application radically improved the microbial activities in the soil, by means of soil buffer capacity (thus chemical soil properties like $\mathrm{pH}$, electrical conductivity, the amount of exchangeable cations, organic matter and total amount of nitrogen content; by means of physical properties: aggregate stability, bulk density, field capacity and wilting point; by means of biological properties: soil respiration and biomass-C content increased (Birol and Bender Özenç, 2011; Aygün, 2015; İslam, 2016).

The application of clinoptilolite, leonardite, organic commercial fertilizer (biofarm) and two different types of hazelnut husk (fresh and composted), which is a regional waste, as soil regulators in a certified organic hazelnut garden revealed positive postharvest developments by means of soil enzymes (dehydrogenase, urease, phosphatase and sulfatase) and the amount of microbial biomass (Özyazıcı et al., 2011).

Soil enzymes are basically produced by soil microorganisms, which are able to show the microbial activities observed in the soil environment and play a crucial role during the decomposition of organic matters and transformation of plant available nutrition elements (Xiu-Mei et al., 2008).

The aim of this study; is to examine the relationship between the effects of the application of the compost, at varying doses, obtained from hazelnut husk by using biotechnological techniques and the effects of sampling seasons on various biological and chemical properties of the soil. 


\section{Materials and methods}

The experiment was carried out in the high tunnel greenhouse established in Ordu University experiment area. The study area is located in Ordu province, Altınordu district, Eastern Black Sea Region, Turkey in 2016. The province of Ordu is located between the northern latitudes of $37 \mathrm{~T} 4534765$, with eastern longitudes of 411638 (Fig. 1).

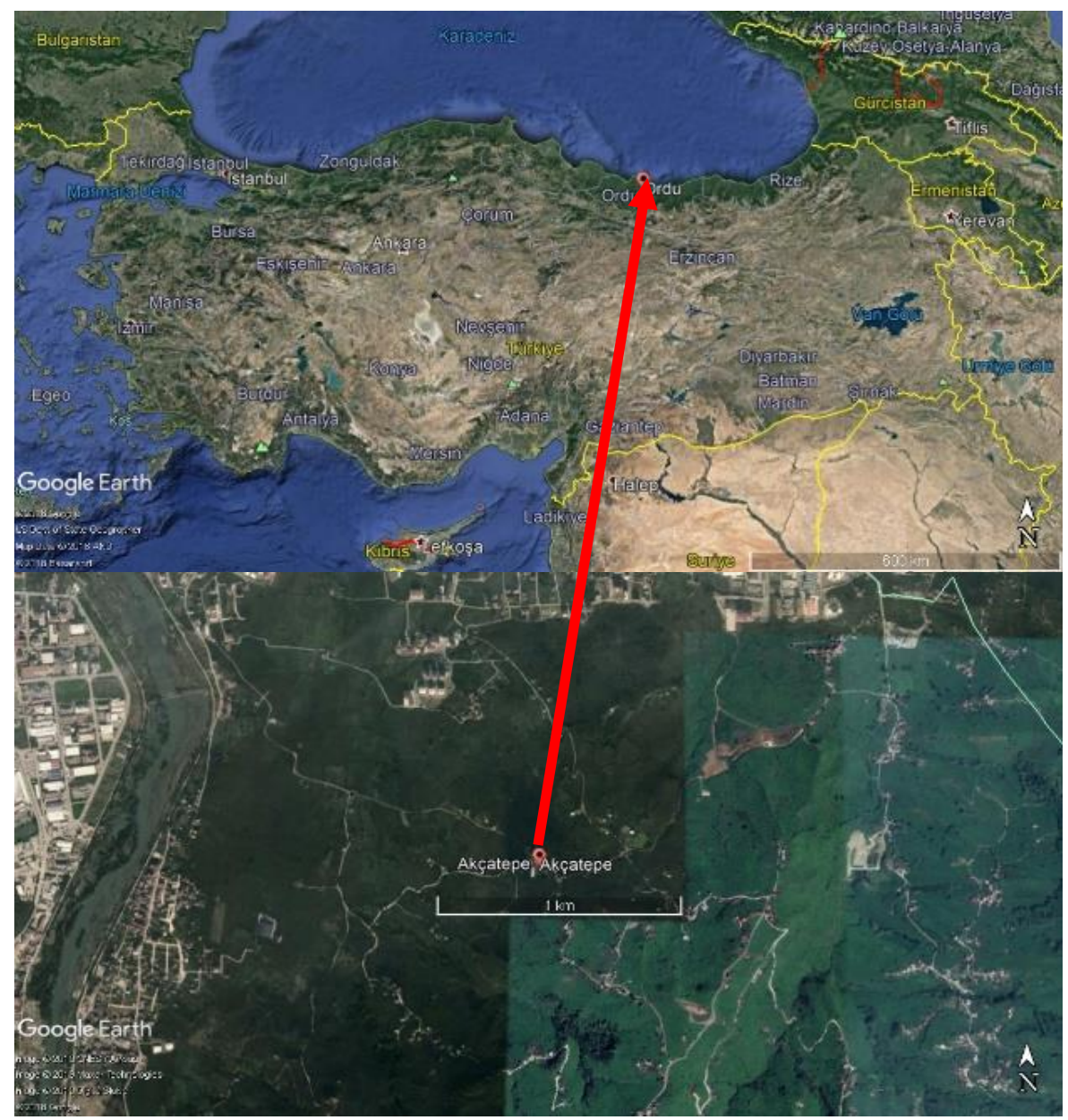

Figure 1. Map shows the location of Akçatepe district experiment area in the Ordu Province, Turkey

In this study, the compost of hazelnut husk, which was obtained by using microbial biotechnological methods, has been used as material. The field test (Akçatepe District) was conducted on the 23rd of November 2012; varying application doses of hazelnut husk compost were applied in order to increase the soils organic material content as of 0 (control), $0.5 \%\left(0.125 \mathrm{~kg} \mathrm{ha}^{-1}\right), 1 \%\left(0.25 \mathrm{~kg} \mathrm{ha}^{-1}\right), 2 \%\left(0.50 \mathrm{~kg} \mathrm{ha}^{-1}\right), 3 \%\left(0.75 \mathrm{~kg} \mathrm{ha}^{-1}\right)$ and $4 \%\left(1 \mathrm{~kg} \mathrm{ha}^{-1}\right)$; the compost was applied uniformly to a $50-60 \mathrm{~cm}$ diameter circle around the hazelnut plots by mattocking and mixing with soil to a $10-15 \mathrm{~cm}$ depth. The sampling was realized in four sampling seasons: autumn (I, 25 November 2016), winter (II, 23 February 2017), spring (III; 24 May 2017) and summer (IV, 22 August 2017). The tests were carried out according to randomized blocks trial design with three replications (Aygün, 2015). Hazelnut husk (C/N ratio 55.71; $\mathrm{pH} 5.81 ; \mathrm{EC} 25^{\circ} \mathrm{C}$ 
$1.93 \mathrm{dS} \mathrm{m}^{-1} ; 0.97 \% \mathrm{~N}$ ) was collected from the hazelnut orchard, inoculated with carbon and the microorganisms used as energy sources were composted by windrow method and eventually used as a material in experiments using a windrow machine in the Research Facility of Soil Science and Plant Nutrition Department at Ondokuz May1s University, Samsun, Turkey. HHC properties are as follows: $\mathrm{pH}$ is $6.76, \mathrm{EC} 25^{\circ} \mathrm{C}$ is $3.56 \mathrm{dS} \mathrm{m}{ }^{-1}$, organic matter $(\mathrm{OM})$ content is $94.75 \%$, total $\mathrm{N}$ content is $2.48 \%$ and $\mathrm{C} / \mathrm{N}$ ratio is 22.16 (Kizılkaya et al., 2015a,b).

The loamy soil of the experiment land in Akçatepe shows a neutral ground reaction and a saline electrical conductivity (Table 1$)$. The lime $\left(\mathrm{CaCO}_{3}\right)$, organic matter content, total nitrogen and available phosphorus contents in Akçatepe soil were adequate (Aygün, 2015).

Table 1. The soils physico-chemical properties (Aygün, 2015)

\begin{tabular}{c|c}
\hline Analyses & Akçatepe Dist. (Ordu Province) \\
\hline \% sand & 33.55 \\
Texture \% silt & 27.86 \\
$\%$ clay & 38.59 \\
Textural class & Loamy soil (CL) \\
Soil reaction-pH $(1 / 2.5)$ & 6.69 \\
Electrical conductivity $\left(\mathrm{dS} \mathrm{m}^{-1}\right)(1 / 2.5)$ & 1.43 \\
Lime content $(\mathrm{CaCO}), \%$ & 5.23 \\
Organic matter, \% & 2.58 \\
Total N, \% & 0.196 \\
Available $\mathrm{P}, \mathrm{mg} \mathrm{kg} \mathrm{kg}^{-1}$ & 15.39 \\
Exchangeable Na, cmol(+) $\mathrm{kg}^{-1}$ & 0.326 \\
Exchangeable $\mathrm{K}, \mathrm{cmol}(+) \mathrm{kg}^{-1}$ & 0.444 \\
Exchangeable Ca, cmol $(+) \mathrm{kg}^{-1}$ & 39.90 \\
Exchangeable $\mathrm{Mg}, \mathrm{cmol}(+) \mathrm{kg}^{-1}$ & 1.26 \\
\hline
\end{tabular}

\section{Soil physico-chemical analyses}

Soil samples, grated to 2 milimeters were kept waiting and prepared for the analyses in $+4{ }^{\circ} \mathrm{C}$ refrigerator immediately after, and biological analyses were initiated. To identify the properties of the sample soil, the texture was examined by hydrometer method as told by Bouyoucos (1962), soil reaction (pH) and saltiness (EC) by U.S. Salinity Laboratory Staff (1954), organic material by Nelson and Sommers (1982), total nitrogen by Bremner (1965), extractable potassium by Knudsen et al. (1982) as told by Müftüoğlu et al. (2012).

\section{Soil biological analyses}

For the biological analyses of the soil; $\mathrm{CO}_{2}$ production was identified using the method told by Isermeyer (1952); microbial biomas-C by Anderson and Domsch (1978), $\beta$-Glucosidase Enzyme activity Eivazı and Tabatabai (1988), urease enzyme activity by Kandeler and Gerber (1988), acid phosphatase enzyme activity by Tabatabai and Bremner (1969) as told by Schinner et al. (1996). 


\section{Statistical analysis}

At the end of the study, the variance analysis of the obtained data was performed using the JMP package program and the important results were evaluated according to the LSD test.

\section{Results and discussion}

The effects of the beta-glucosidase enzyme activity $(\mathrm{p}<0.01)$, urease enzyme activity $(\mathrm{p}<0.01)$ and acid phosphatase enzyme activity $(\mathrm{p}<0.01)$ were relevant to application and season interactions effect revealed statistically significant results (Table 2). When the application doses of hazelnut husk compost and sampling seasons are taken into consideration, the highest $\beta$-glucosidase enzyme activity occurred at 0.1 $\mathrm{kg} \mathrm{ha}^{-1}$ compost dose on the 4th season (summer), this value has been followed by the 2nd season (winter) application with a compost dose of $0.25 \mathrm{~kg} \mathrm{ha}^{-1}$ and the lowest control was detected on the 1st season (autumn). As both the hazelnut husk compost application doses on the 4th season (summer) and sampling seasons multiplied, the beta- glucosidase enzyme activity of soils increased accordingly. It has been stated that the soil organic matter absorbs the beta-glucosidase enzyme and therefore induces the activity in the soil to continue (Wang et al., 2006). The $\beta$-Glucosidase enzyme activity is one of the essential soil enzymes, which is responsible for the $\mathrm{C}$ cycle (Nannipieri et al., 2002; Kayıkçıoglu and Okur, 2011).

The urease enzyme activity's peak (73.55) occurred on the 1st season (winter) at a dose of $0.75 \mathrm{~kg} \mathrm{ha}^{-1}$, this was followed by the $0.125 \mathrm{~kg} \mathrm{ha}^{-1}$ dose and these two doses were identified as the most effective ones. The lowest urease enzyme activity dose was $0.50 \mathrm{~kg} \mathrm{ha}^{-1}$ and it was identified on the 4th season (summer). The applications of hazelnut husk increased the soils urease enzyme activity; however, during the summer season the increasing temperature accelerated the decomposition of organic materials, resulting in the 4th sampling season (summer) to reveal the lowest urease enzyme activity values.

Table 2. The effects of application seasons of the hazelnut husk compost on the $\beta$ glucosidase, urease and acid phosphatase enzyme activities

\begin{tabular}{|c|c|c|c|c|c|c|c|c|c|c|c|c|c|c|}
\hline \multicolumn{5}{|c|}{$\begin{array}{l}\text { Beta glucosidase enzyme activity } \\
\text { (mg p-nitrophenol gr dry soil } \mathbf{h}^{-1} \text { ) }\end{array}$} & \multicolumn{5}{|c|}{$\begin{array}{l}\text { Urease enzyme activity } \\
\left(\mu \mathrm{g} \mathrm{N} \text { gr dry. } \text { soil }^{-1} 2 \mathrm{~h}^{1}\right)\end{array}$} & \multicolumn{5}{|c|}{$\begin{array}{l}\text { Acid phosphatase enzyme activity } \\
\left(\mu \mathrm{g} P-\mathrm{N} \text { gr dry. soil }^{-1}\right)\end{array}$} \\
\hline $\begin{array}{c}\text { Doses } \\
\left(\mathrm{kg} \mathrm{ha}^{-1}\right)\end{array}$ & 1.P & 2.P & 3.P & 4.P & $\begin{array}{c}\text { Doses } \\
\left(\mathrm{kg} \mathrm{ha}^{-1}\right)\end{array}$ & 1.P & 2.P & 3.P & 4.P & $\begin{array}{c}\text { Doses } \\
\left(\mathrm{kg} \mathrm{ha}^{-1}\right)\end{array}$ & $1 . P$ & 2.P & 3.P & 4.P \\
\hline 0 & $1.98 \mathrm{fg}$ & 7.03efg & 8.91efg & $1.76 \mathrm{~g}$ & $\mathbf{0}$ & $12.58 \mathrm{e}-\mathrm{g}$ & $16.97 \mathrm{e}-\mathrm{g}$ & $9.96 \mathrm{e}-\mathrm{g}$ & $5.26 \mathrm{fg}$ & 0 & $6.01 \mathrm{c}-\mathrm{f}$ & $5.32 \mathrm{c}-\mathrm{f}$ & $8.25 \mathrm{c}-\mathrm{f}$ & $1.76 \mathrm{f}$ \\
\hline 0.125 & $2.15 \mathrm{fg}$ & $13.42 \mathrm{c}-\mathrm{g}$ & $12.13 \mathrm{c}-\mathrm{g}$ & $8.28 \mathrm{e}-\mathrm{g}$ & 0.125 & $67.93 a$ & $22.74 \mathrm{c}-\mathrm{g}$ & $18.61 \mathrm{~d}-\mathrm{g}$ & $5.66 f g$ & 0.125 & 6.61c-f & 4.70d-f & $11.23 \mathrm{~cd}$ & $8.28 \mathrm{c}-\mathrm{f}$ \\
\hline 0.25 & $4.75 \mathrm{efg}$ & $28.83 \mathrm{ab}$ & $15.11 \mathrm{c}-\mathrm{f}$ & $10.47 \mathrm{~d}-\mathrm{g}$ & 0.25 & 63.26ab & $29.70 \mathrm{c}-\mathrm{e}$ & $13.44 \mathrm{e}-\mathrm{g}$ & $5.45 f g$ & 0.25 & $12.34 \mathrm{c}$ & 7.45d-f & $30.34 \mathrm{ab}$ & $10.47 \mathrm{~cd}$ \\
\hline 0.5 & $3.52 \mathrm{fg}$ & $15.1 \mathrm{c}-\mathrm{f}$ & $17.81 \mathrm{~b}-\mathrm{e}$ & $4.14 \mathrm{fg}$ & 0.5 & $43.40 \mathrm{bc}$ & $24.67 \mathrm{c}-\mathrm{g}$ & $19.52 \mathrm{~d}-\mathrm{g}$ & $4.14 \mathrm{~g}$ & 0.5 & $9.20 \mathrm{c}-\mathrm{e}$ & $4.90 \mathrm{~d}-\mathrm{f}$ & $23.04 \mathrm{~b}$ & $4.13 \mathrm{~d}-\mathrm{f}$ \\
\hline 0.75 & $2.78 \mathrm{fg}$ & $25.07 \mathrm{abc}$ & 22.35a-d & $2.5 \mathrm{fg}$ & 0.75 & $73.55 \mathrm{a}$ & $20.95 \mathrm{~d}-\mathrm{g}$ & $22.15 \mathrm{~d}-\mathrm{g}$ & $5.25 \mathrm{fg}$ & 0.75 & 8.40c-f & $6.09 \mathrm{c}-\mathrm{f}$ & $27.16 \mathrm{ab}$ & $2.50 \mathrm{ef}$ \\
\hline 1 & $3.23 \mathrm{fg}$ & $10.61 \mathrm{~d}-\mathrm{g}$ & $13.28 \mathrm{c}-\mathrm{g}$ & $32.15 \mathrm{a}$ & 1 & $30.20 \mathrm{c}-\mathrm{e}$ & $37.87 \mathrm{~cd}$ & $25.21 \mathrm{c}-\mathrm{f}$ & $5.78 \mathrm{fg}$ & 1 & $6.57 \mathrm{c}-\mathrm{f}$ & $5.57 \mathrm{c}-\mathrm{f}$ & $30.14 \mathrm{ab}$ & $32.15 \mathrm{a}$ \\
\hline \multicolumn{5}{|c|}{ LSD $(p<0.01)=6.55826$} & \multicolumn{5}{|c|}{$\operatorname{LSD}(\mathrm{p}<0.01)=10.329$} & \multicolumn{5}{|c|}{ LSD $(p<0.01)=3.68094$} \\
\hline
\end{tabular}

As the strongest acid phosphatase enzyme activity occurs in the beta-glucosidase enzyme activity, a $1 \mathrm{~kg} \mathrm{ha}^{-1}$ dose application of the hazelnut husk compost on the 4th sampling season (summer) revealed the highest values (32.15 $\mu \mathrm{g} P$ - N g.d.s ${ }^{-1}$ ), whereas the lowest acid phosphatase enzyme activity value was identified during an application of a $1.25 \mathrm{~kg} \mathrm{ha}^{-1}$ dose and on the 2 nd (winter) sampling season (4.70 $\left.\mu \mathrm{g} P-\mathrm{N} \mathrm{g.d.s^{-1 }}\right)$. In 
previous studies, the effects of vegetable substances like wheat and corn stalk and as animal products, the effects of horse, hog and cow manure on soils were investigated, ultimately it was determined that all these applications boost the urease, phosphatase and interphase activities, revealing the lowest rate of increase in the interphase activity and the highest in urease and phosphatase activities (Guan, 1989; Aygün, 2015).

Among the application doses of the hazelnut husk compost, the highest soil respiration $(0.60 \mathrm{mg} \mathrm{CO} / 24 \mathrm{~h} / \mathrm{g})$ was detected at the $0.25 \mathrm{~kg} \mathrm{ha}^{-1}$ application dose and the lowest $(0.42 \mathrm{mg} \mathrm{CO} / 24 \mathrm{~h} / \mathrm{g})$ at the compost's control application. The difference between these values was statistically highly significant $(p<0.01)$. Furthermore, through the application of this dose, the $\mathrm{CO}_{2}$ production value revealed a 1.4 times increase comparing to the control application (Table 3).

Considering the sampling seasons, the highest $\mathrm{CO}_{2}$ production value was identified on the $1 \mathrm{st}$ and 4 th seasons (autumn and summer) $(0.30 \mathrm{mg} \mathrm{CO} / 24 \mathrm{~h} / \mathrm{g})$, whereas the lowest value was identified on the $3 \mathrm{rd}$ season (spring) $(0.21 \mathrm{mg} \mathrm{CO} / 24 \mathrm{~h} / \mathrm{g})$. The difference between these seasonal values was statistically highly significant $(\mathrm{p}<0.01)$. The $\mathrm{CO}_{2}$ production on the loamy soil of the experiment area, decreased gradually from the 1st sampling season (spring) to the 3rd (winter) and increased again on the 4th season (summer). The $\mathrm{CO}_{2}$ formation in agricultural soils usually varies between 3.5 and $35 \mathrm{mg} \mathrm{CO}$-C 100 g.d.s $\mathrm{s}^{-1}$ values (Alexander, 1961; Kayıkçığlu and Okur, 2013). It has been stated that the $\mathrm{CO}_{2}$ amount in organic farms is higher than in conventional agriculture farms (Melero, 2006; Tuomisto et al., 2012).

Table 3. The effects of application doses of the hazelnut husk compost on the sampling seasons, $\mathrm{CO}_{2}$ production ( $\mathrm{mg} \mathrm{CO}_{2} / 100 \mathrm{~g}^{-1}$ day ${ }^{-1}$ ) based on doses, microbial biomass $-\mathrm{C}$ (MBC mg biyomas-C 100 g.d.s s. $^{-1}$ and other soil properties (organic matter OM:\%, total $N$ \%, K: $\mathrm{mg} \mathrm{kg}^{-1}, \mathrm{Mg}$ and $\left.\mathrm{Ca}: \mathrm{Cmol}_{(+)} \mathrm{kg}^{-1}\right)$

\begin{tabular}{c|c|c|c|c|c|c|c|c|c|c}
\hline & \multicolumn{9}{|c|}{ Doses } & \multicolumn{4}{c}{ Season } \\
\hline & 0 & 1.25 & 2.5 & 5 & 7.5 & 10 & 1 & 2 & 3 & 4 \\
$\mathrm{CO}_{2}$ & $0.42 \mathrm{~b}$ & $0.58 \mathrm{a}$ & $0.60 \mathrm{a}$ & $0.58 \mathrm{a}$ & $0.54 \mathrm{a}$ & $0.52 \mathrm{a}$ & $1.30 \mathrm{a}$ & $0.28 \mathrm{c}$ & $0.21 \mathrm{c}$ & $1.30 \mathrm{a}$ \\
$\mathrm{MBC}$ & $42.60 \mathrm{~b}$ & $68.83 \mathrm{a}$ & $67.50 \mathrm{a}$ & $74.85 \mathrm{a}$ & $70.13 \mathrm{a}$ & $69.16 \mathrm{a}$ & $24.82 \mathrm{c}$ & $52.05 \mathrm{~b}$ & $14.20 \mathrm{c}$ & $170.98 \mathrm{a}$ \\
$\mathrm{OM}$ & 1.60 & 1.71 & 1.65 & 1.41 & 1.38 & 1.61 & $1.43 \mathrm{~b}$ & $1.93 \mathrm{a}$ & $1.35 \mathrm{~b}$ & $1.53 \mathrm{ab}$ \\
Total N & 0.13 & 0.14 & 0.13 & 0.12 & 0.13 & 0.13 & $0.10 \mathrm{c}$ & $0.50 \mathrm{a}$ & $0.13 \mathrm{bc}$ & $0.14 \mathrm{ab}$ \\
$\mathrm{K}$ & $162 \mathrm{~b}$ & $176 \mathrm{~b}$ & $185 \mathrm{~b}$ & $199 \mathrm{~b}$ & $202 \mathrm{~b}$ & $266 \mathrm{a}$ & 204 & 207 & 205 & 178 \\
$\mathrm{Mg}$ & $5.09 \mathrm{c}$ & $6.12 \mathrm{bc}$ & $6.72 \mathrm{ab}$ & $5.97 \mathrm{bc}$ & $7.70 \mathrm{a}$ & $6.90 \mathrm{ab}$ & $8.40 \mathrm{a}$ & $5.60 \mathrm{~b}$ & $6.04 \mathrm{~b}$ & $5.60 \mathrm{~b}$ \\
$\mathrm{Ca}$ & $26.82 \mathrm{a}$ & $24.41 \mathrm{ab}$ & $24.28 \mathrm{abc}$ & $22.17 \mathrm{bc}$ & $20.71 \mathrm{~cd}$ & $17.36 \mathrm{~d}$ & $18.22 \mathrm{c}$ & $26.47 \mathrm{a}$ & $23.84 \mathrm{ab}$ & $22.00 \mathrm{~b}$ \\
$\mathrm{pH}$ & $6.70 \mathrm{a}$ & $6.36 \mathrm{ab}$ & $6.23 \mathrm{~b}$ & $6.20 \mathrm{~b}$ & $6.10 \mathrm{~b}$ & $6.03 \mathrm{~b}$ & $6.52 \mathrm{a}$ & $6.16 \mathrm{~b}$ & $6.32 \mathrm{ab}$ & $6.08 \mathrm{~b}$ \\
\hline
\end{tabular}

When the application doses of hazelnut husk are taken into consideration, the microbial biomass $-\mathrm{C}$ (MBC) value was between $42.60-74.85 \mathrm{mg}$ biomass-C 100 g.d.s ${ }^{-1}$ and the difference between the hazelnut husk doses were statistically insignificant $(\mathrm{p}<0.01)$. The doses have increased the MBC values comparing to the control and the highest value was identified at a dose of $0.5 \mathrm{~kg} \mathrm{ha}^{-1}$.

When the sampling season is considered, the MBC value showed a regular increase from the 1st (autumn) season to the 4th (summer) season (except the 3rd- spring season); the highest value arose on the 4th season (summer) and the difference between seasons was statistically significant $(\mathrm{p}<0.01)$. 
In respect to hazelnut husk doses, organic matter $(\mathrm{OM})$ content increased and this increment showed seasonal changes. The effects of doses were statistically insignificant, however the highest value has been observed at a dose of $0.125 \mathrm{~kg} \mathrm{ha}^{-1}$. When taking the sampling seasons into account, the highest organic material value was detected on the 2nd season (winter). The loamy soils own high surface areas and a high cation exchange capacity, thus showing protective features against the fragmentation of organic substances (Giller et al., 1997; Aygün, 2015). It was reported that organic waste applications radically improve the chemical features of loamy sand soils like the content of organic matter and exchangeable cations and enhance the soil quality (Candemir and Gülser, 2011). There are also other studies, which explain that hazelnut husk may be utilized as an organic material and nutritional source, which enhances the physical properties of the soils (Zeytin and Baran, 2003; Bender Özenç et al., 2019).

Garcia et al. (2004) investigated the effects of various plants on $\mathrm{pH}, \mathrm{EC}$, total organic carbon and carbon fractions, microbial biomass carbon, soil respiration, dehydrogenase, phosphatase, $\beta$-glycosidase and urease characteristics for 6 years. At the end of the researches they reported that; the aggregate stability, soil respiration, dehydrogenase, urease and phosphatase activities occur more strongly in plant growing soils; $\mathrm{pH}$ (7.58.0) and EC levels are lower compared to control; the total organic carbon and microbial biomass carbon available in the rhizosphere zone are higher compared to control application.

In consequence of statistical evaluations, the effects of hazelnut husk applications on total $\mathrm{N}$ were found insignificant, remaining within an interval of \% 0.12-0.14 and showing the highest results at a dose of $0.25 \mathrm{~kg} \mathrm{ha}^{-1}$. However the sampling season was statistically significant $(\mathrm{p}<0.01)$. When sampling seasons are considered, it was determined that the 2nd season (winter) revealed the highest total $\mathrm{N}$ content $(0.50 \%)$, while the 1st season (autumn) demonstrated the lowest total $\mathrm{N}$ content $(0.10 \%)$. Shenbagavalli and Mahimairaja (2012) on the other hand reported that as the incubation season extends, the mineral $\mathrm{N}$ values radically reduce. Besides, as an expected result, when the microorganisms decompose the organic materials in the soil in order to create a source of nitrogen, the nitrogen content of the soil decreases (Bender Özenç et al., 2019).

The effects of hazelnut husk compost doses on extractable $\mathrm{K}$ were significant $(\mathrm{p}<0.01)$. The application of the hazelnut husk compost in different doses, increased the extractable $\mathrm{K}$ content of the soil. The highest $\mathrm{K}$ value was detected at a dose of $1 \mathrm{~kg} \mathrm{ha}^{-1}\left(266 \mathrm{mg} \mathrm{kg}^{-1}\right)$ and increased 1.65 times compared to control.

In terms of the exchangeable $\mathrm{Mg}$ and $\mathrm{Ca}$ values, doses and sampling seasons were statistically significant $(\mathrm{p}<0.01)$. According to doses, the exchangeable $\mathrm{Mg}$ value was between 7.70-5.09 $\mathrm{cmol}_{(+)} \mathrm{kg}^{-1}$ and the highest dose was $0.75 \mathrm{~kg} \mathrm{ha}^{-1}$, the exchangeable $\mathrm{Ca}$ value on the other hand was between 17.36-26.82 $\mathrm{cmol}_{(+)} \mathrm{kg}^{-1}$, showing the highest value at the control dose. The exchangeable $\mathrm{Mg}$ and $\mathrm{Ca}$ values were statistically significant in consideration of sampling seasons. The exchangeable $\mathrm{Mg}$ highest value $\left(8.40 \mathrm{cmol}_{(+)} \mathrm{kg}^{-1}\right)$ was identified on the 1st sampling season (autumn), while it was the lowest $\left(5.6 \mathrm{cmol}_{(+)} \mathrm{kg}^{-1}\right)$ during the 2nd (winter) and 4th (summer) sampling seasons. The exchangeable Ca value was between 18.22-26.47 $\mathrm{cmol}_{(+)} \mathrm{kg}^{-1}$ (2nd-winter and 1stautumn season).

When the soil reaction is analyzed, the effects of the hazelnut husk compost on doses and sampling times revealed statistically significant results $(\mathrm{p}<0.01)$. The highest $\mathrm{pH}$ value was identified at the control application (6.70), the lowest $\mathrm{pH}$ value on the other 
hand was determined at a compost application dose of $1 \mathrm{~kg} \mathrm{ha}^{-1}$ (6.03). And when the sampling seasons are examined, the highest value was observed at the 1st (autumn) (6.52) and the lowest at the 4th (summer) season (6.08).

\section{Conclusion}

Within the scope of this study, where the effects of different application doses and sampling seasons of hazelnut husk compost, obtained through microbial biotechnological methods, on the soil various biological features were examined, the biological soil properties showed improvements and positive developments. While the beta-glucosidase and acid phosphatase enzyme activities were the highest at a dose of $1 \mathrm{~kg} \mathrm{ha}^{-1}$, the most effective sampling season was the 4th (summer) one. Urease enzyme activity on the other hand was more effective during the 1st (autumn) season and the $0.75 \mathrm{~kg} \mathrm{ha}^{-1}$ dose was sufficient. For the production of $\mathrm{CO}_{2}$ the $0.25 \mathrm{~kg} \mathrm{ha}^{-1}$ dose, for MBC the $0.5 \mathrm{~kg} \mathrm{ha}^{-1}$ dose, for total $\mathrm{N}$ and organic matter content the $0.125 \mathrm{~kg} \mathrm{ha}^{-1}$ dose were sufficient. To blend the hazelnut husk compost, which is an organic material containing a large amount of organic matter, with the soil, provided the soil organic matter content to increase, which ultimately was an intended result. Increased doses of hazelnut husk compost to the soil, although there is an increase in the amount of organic matter due to dose increase. The optimum level of the compost to be applied must be decided, the initial organic matter content of the soil is recommended.

\section{REFERENCES}

[1] Alexander, M. (1961): Introduction to Soil Microbiology. - John Wiley and Sons, Inc., New York.

[2] Amiri, H., Ismaili, A., Hosseinzadeh, S. R. (2017): Influence of vermicompost fertilizer and water deficit stress on morpho-physiological features of chickpea (Cicer arietinum L. cv. Karaj). - Compost Science \& Utilization 25(3): 152-165.

[3] Anderson, T. H., Domsch. K. H. (1978): A physiological method for the quantitative measurement of microbial biomass in soils. - Soil Biology and Chemistry 10: 215-221.

[4] Aygün, S. (2015): The effect of adding of hazelnut husk compost on soil quality, Findık zurufu kompostunun toprak kalitesi üzerine etkisi. - MSC Thesis University of Ordu, Institute for Graduate Studies in Science and Technology Department of Soil Science and Plant Nutrition, Ordu, Turkey.

[5] Birol Y., Bender Özenç D (2011): Fındık zuruf kompostunun sıkıştırılmış killi tınlı bir toprağın fiziksel özellikleri üzerine etkisi. - Prof. Dr. Nuri Munsuz Ulusal Toprak ve Su Sempozyumu, Ankara, pp. 77-85.

[6] Bouyoucos, G. J. (1962): Hydrometer method improved for making particle size analysis of soil. - Agronomy Journal 545: 434-438.

[7] Bremner, J. M. (1965): Total Nitrogen 1. - In: Page, A. L. (ed.) Methods of Soil Analysis. Part 2. Chemical and Microbiological Properties. ASA, Madison, WI, pp. 11491178.

[8] Çalışkan N., Koç N., Kaya A., Şenses T. (1996): Obtaining the Hazelnut Husk Compost (Fındık Zurufundan Kompost Elde Edilmesi). - Fındık Araştırma Enstitüsü Müdürlüğü Sonuç Raporu, Giresun.

[9] Candemir, F., and Gülser, C. (2011): Effects of different agricultural wastes on some soil quality indexes in clay and loamy sand fields. - Communications in Soil Science and Plant Analysis 42(1): 13-28. 
[10] Eivazi F., Tabatabai M. A. (1988): Glucosidases and galactosidases in soils. - Soil Biology and Biochemistry 20(5): 601-606.

[11] FAO (2019): Hazelnut production. http://www.fao.org/3/x4484e/x4484e03.htm\#TopOfPage (access: 30.10.2019).

[12] Garcia, C., Roldan, A., Hernandez, T. (2004): Ability of different plant species to promote microbiological processes in semiarid soil. - Geoderma 124: 193-202.

[13] Giller, K. E., Cadish, G., Ehaliotis, C., Adams, E., Sakala, W., Mafongoya, P. (1997): Building Soil Nitrogen Capital in Africa. - In: Buresh, R. J., Sanchez, P. A., Calhoun, F. (eds.) Replenishing Soil Fertility in Africa. SSSA Special Publication No. 51, Madison, WI, pp. 151-192.

[14] GTB (2013): Gümrük ve Ticaret Bakanlığı 2013 Yılı Fındık Raporu. http://koop.gtb.gov.tr/data/5342b62e487c8ea5e4b4d9bc/2013\%20F\%C4\%B1nd\%C4\%B 1k\%20Raporu.pdf (date of access: 03.04.2015).

[15] Guan, S. Y. (1989): Studies on the factors influencing soil enzyme activities: I. Effects of organic manures on soil enzyme activities and $\mathrm{N}$ and $\mathrm{P}$ transformations. - Acta Pedologica Sinica 26: 72-78.

[16] İslam, E. (2016): The Effect of Hazelnut Husk Compost on Soil Mechanical Properties (Fındık Zurufu Kompostunun Toprak Mekaniksel Özellikleri Üzerine Etkisi). - Ordu Üniversitesi Fen Bilimleri Enstitüsü, Toprak Bilimi ve Bitki Besleme Anabilim Dalı, Yüksek Lisans Tezi.

[17] Kandeler, E., Gerber, H. (1988): Short-term assay of soil urease activity using colorimetric determination of ammonium. - Biology and Fertility of Soils 6(1): 68-72.

[18] Kayikçioğlu, H. H., Okur, N. (2011): Evolution of enzyme activities during composting of tobacco waste. - Waste Management \& Research 29(11): 1124-1133.

[19] Kayıkçığlu, H. H., Okur, N. (2013): Seasonal changes of microbial biomass-C, N and P in soils under different plant covers. - Ege Üniversitesi Ziraat Fakültesi Dergisi 50(1): 57-65.

[20] Kizılkaya, R., Sahin, N., Askin, T., Sushkova, S. (2015a): Isolation, characterization and genetic identification of natural fungal strains from decomposing hazelnut husk. - 50th Croatian \& 10th International Symposium on Agriculture. February 16-20, 2015, Opatija, Crotia.

[21] Kizılkaya, R., Sahin, N., Tatar, D., Veyisoglu, A., Askin, T., Sushkova, S. N., Minkina, T. (2015b): Isolation and identification of bacterial strains from decomposing hazelnut husk. - Compost Science \& Utilization 23(3): 173-184.

[22] Knudsen, D., Peterson, G. A., Pratt, P. F. (1982): Lithium, Sodium, and Potassium. - In: Page, A. L. (ed.) Methods of Soil Analysis. Part 2. Chemical and Microbiological Properties. ASA, Madison, WI, pp. 225-246.

[23] Melero, S., Porras, J. C. R., Herencia, J. F., Madejon, E. (2006): Chemical and biochemical properties in a silty loam soil under conventional and organic management. Soil \& Tillage Research 90: 162-170.

[24] Meli, S., Porto M., Belligno, A., Bufo, S. A., Mazzatura, A., Scapa, A. (2002): Influence of irrigation with lagooned urban wastewater on chemical and microbiological soil parameters in a citrus orchard under Mediterranean condition. - Sci. Total Environ. 285: 69-77.

[25] Müftüoğlu, N. M., Türkmen, C., Çıkılı, Y. (2012): Soil and Plant Fertility Analysis (Toprak ve Bitkide Verimlilik Analizleri, Kriter Yayınevi). - Nobel, Ankara.

[26] Nannipieri, P., Kandeler, E., Ruggiero, P. (2002): Enzyme Activities and Microbiological and Biochemical Processes in Soil. - In: Burns, R. G., Dick, R. P. (eds.) Enzymes in the Environment. Marcel Dekker, New York, pp. 1-33.

[27] Nelson, D. W., Sommers, L. E. (1982): Total Carbon, Organic Carbon and Soil Organic Matter. - In: Page, A. L. et al. (eds.) Methods of Soil Analysis. Part 2: Chemical and Microbiological Properties. ASA-SSSA, Madison, WI, pp. 539-579. 
[28] Özenç, D. B. (2008): Growth and transpiration of tomato seedlings grown in Hazelnut Husk compost under water-deficit stress. - Compost Science \& Utilization 16(2): 125131.

[29] Özenç, D. B., Yılmaz, F. I., Tarakçıoğlu, C., Aygün, S. (2019): Findıktan üretilen atıkların toprağın fiziko-kimyasal ve biyolojik özelliklerine etkileri. Effects of hazelnut produced wastes on physico-chemical and biological properties of soil. - Mediterranean Agricultural Sciences 32: 7-13.

[30] Ozyazıcı, G., Ozdemir, O., Ozyazıcı, M. A., Ustun, G. Y. (2011): The effects of organic materials and soil regulators in organic hazelnut production on yield and some soil properties (Bazı organik materyallerin ve toprak düzenleyicilerin organik findık yetiştiriciliğinde verim ve toprak özellikleri üzerine etkileri). - Poster at Türkiye IV. Organik Tarım Sempozyumu, Erzurum, 28 Haziran-1 Temmuz 2010.

[31] Schinner, F., Öhlinger, R., Kandeler, E., Margesin, R. (eds.) (1996): Methods in Soil Biology. - Springer-Verlag, Berlin.

[32] Sermeyer, H. (1952): Eine einfache Methode zur Bestimmung der Karbonate im Boden. Zeitschrift für Pflanzenernährung, Düngung, Bodenkunde 561(3): 26-38.

[33] Shenbagavalli, S., Mahimairaja, S. (2012). Characterization and effect of biochar on nitrogen and carbon dynamics in soil. - International Journal of Advanced Biological Research 2(2): 249-255.

[34] Stévigny, C., Rolle, L., Valentini, N., Zeppa, G. (2007). Optimization of extraction of phenolic content from hazelnut shell using response surface methodology. - Journal of the Science of Food and Agriculture 87(15): 2817-2822.

[35] Tabatabai, M. A., Bremner, J. M. (1969): Use of p-nitrophenyl phosphate for assay of soil phosphatase activity. - Soil Biology and Biochemistry 1(4): 301-307.

[36] Tous, M. J. (2001): Hazelnut technology for warm climates. - Proceedings of the Ninth Australasian Conference on Trees and Nut Crops, Perth, Western Australia.

[37] Tuomisto, H. L., Hodge, I. D., Riordan, P., Macdonald, D. W. (2012). Does organic farming reduce environmental impacts? A meta-analysis of European research. - Journal of Environmental Management 112: 309-320.

[38] U.S. Salinity Laboratory Staff (1954): Diagnosis and Improvement of Saline and Alkali Soils. - Handbook No. 60. U.S. Salinity Laboratory, Riverside, CA.

[39] Wang, L., Zhang, Y., Gao, P., Shi, D., Liu, H., Gao, H. (2006). Changes in the structural properties and rate of hydrolysis of cotton fibers during extended enzymatic hydrolysis. Biotechnology and Bioengineering 93(3): 443-456.

[40] Xiao-Chang, W. A. N. G., Qin, L. (2006): Beta-glucosidase activity in paddy soils of the Taihu Lake region, China. - Pedosphere 16(1): 118-124.

[41] Xiu-Mei, L. I. U., Qi, L. I., Liang, W. J., Jiang, Y. (2008): Distribution of soil enzyme activities and microbial biomass along a latitudinal gradient in farmlands of Songliao Plain, Northeast China. - Pedosphere 18(4): 431-440.

[42] Zeytin, S., Baran, A. (2003): Influences of composted hazelnut husk on some physical properties of soils. - Bioresource Technology 88(3): 241-244. 